\title{
Penerapan Algoritma C4.5 untuk Klasifikasi Data Rekam Medis berdasarkan International Classification Diseases (ICD-10)
}

\author{
Yudha Aditya Fiandra ${ }^{\mathrm{a}}$, Sarjon Defit ${ }^{\mathrm{b}}$, Yuhandri ${ }^{\mathrm{c}}$ \\ ${ }^{a}$ Pasca Sarjana, Magister Komputer, Universitas Putra Indonesia, yudhaaditya1994@gmail.com \\ basca Sarjana, Magister Komputer, Universitas Putra Indonesia, sarjonde@yahoo.co.uk \\ ${ }^{\mathrm{c}}$ Pasca Sarjana, Magister Komputer, Universitas Putra Indonesia, yuhandri.yunus@gmail.com
}

\begin{abstract}
The medical record data is the patient's current record of medical records, the medical record data only being data stacked and not traced to generate useful knowledge for the hospital. This study can process the medical record data to classify the disease that occurs in sleeping sickness based on ICD-10. The method used in this research is C4.5 algorithm method by using attribute of international disease code as attribute of destination label as many as 21 international disease group, that is: A00-B99 up to Z00-Z99. This study yields a decision of the value code, C4.5 code can represent as many as 14 attribute values of disease code objectives and data percentage that read more than $66 \%$. The conclusion of this research is $C 4.5$ algorithm help classify international disease code based on ICD-10 and decision tree making which can give information of any disease that often happened at hospital
\end{abstract}

Keywords: data mining, classification, C4.5, medical records, ICD-10

\begin{abstract}
Abstrak
Data rekam medis adalah catatan khusus pasien yang sedang, seringkali data rekam medis hanya menjadi data yang menumpuk dan tidak dilakukan penelusuran untuk menghasilkan pengetahuan yang berguna bagi rumah sakit. Penelitian ini bertujuan mengolah tumpukan data rekam medis untuk mengklasifikasikan jenis penyakit yang terjadi pada rumah sakit berdasarkan pada kode penyakit internasional (International Classification of Disease) ICD-10. Metode yang digunakan dalam penelitian ini adalah metode algoritma C4.5 dengan menggunakan atribut kode penyakit internasional sebagai atribut label tujuan sebanyak 21 kelompok penyakit internasional, yaitu: A00-B99 sampai dengan Z00-Z99. Penilitian ini menghasilkan pohon keputusan dari 21 berupa value atribut tujuan kode penyakit, algoritma C4.5 dapat merepresentasikan sebanyak 14 value atribut tujuan kode penyakit dan persentasi data yang terbaca lebih dari $66 \%$. Kesimpulan dari penelitian ini yaitu algoritma C4.5 membantu mengklasifikasikan kode penyakit internasional berdasarkan ICD-10 dan membentuk pohon keputusan yang dapat memberikan informasi penyakit apa saja yang sering terjadi pada rumah sakit
\end{abstract}

Kata kunci: data mining, klasifikasi, C4.5, rekam medis, ICD-10

(C) 2017Jurnal RESTI

\section{Pendahuluan}

Knowledge discovery in database (KDD) merupakan proses untuk menemukan informasi yang berguna dalam database. Seluruh proses KDD biasanya terdiri dari langkah-langkah, yaitu memahami bidang aplikasi, membuat data target yang ditetapkan dari data mentah yang tersimpan dalam database, pembersihan data dan preprocessing data [1].

Istilah knowledge discovery in database atau mencari pengetahuan dalam database atau KDD singkatnya, mengacu pada proses pencarian pengetahuan dalam data yang luas dan menekankan pada penerapan metode tingkat tinggi atau metode penambangan data tertentu. Ini menarik minat para peneliti dalam melakukan pengembang penelitian baik dalam bidang machine learning atau pembelajaran mesin [2].

Pendekatan data mining menjadi sangat penting dalam industri kesehatan dalam mengambil keputusan berdasarkan analisis dari data klinis yang besar. Data mining berperan dalam proses mengekstrak informasi tersembunyi dari dataset yang besar dan teknik-teknik seperti klasifikasi, clustering, regresi dan asosiasi telah digunakan oleh bidang medis [3]. 


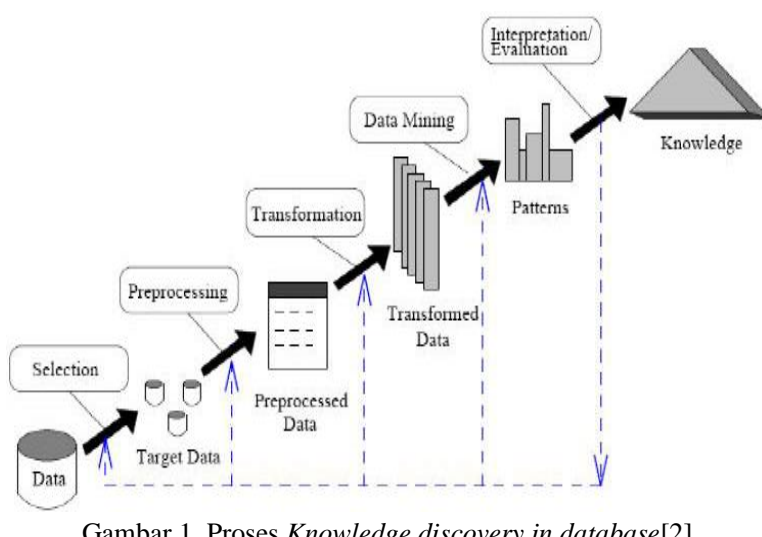

Salah satu teknik klasifikasi yang sering digunakan oleh peneliti adalah penerapan algoritma C4.5. Algoritma C4.5 adalah algoritma yang menghasilkan pohon keputusan Ini memiliki masukan berupa sampel klasifikasi [4]. Penerapan fungsi algoritma C4.5 untuk menghasilkan tingkat akurasi data sebagai dataset yang mengandung data dalam jumlah besar [5].

\section{Tinjauan Pustaka/Penelitian Sebelumnya}

Khusus untuk fungsionalitas data mining menggunakan klasifikasi, beberapa penelitian telah dilakukan misalnya oleh Wenefrida pada tahun 2013 [6], mengenai klasifikasi data rekam medis berdasarkan kode penyakit internasional dimana dalam penelitian ini terfokus pada bagaimana melakukan klasifikasi data rekam medis pasien agar diklasifikasikan berdasarkan kode penyakit menurut standar ICD-10. Klasifikasi penyakit berdasarkan tumpukan data rekam medis, menggunakan salah satu metode dalam data mining, yaitu algoritma $\mathrm{C} 4.5$, untuk mencapai tujuan penelitian, maka dipilih 4 atribut sesuai data rekam medis. Data rekam medis yangdimaksud terdiri dari atribut diagnosa penyakit berdasarkan International Classification of Diseases-10th (ICD-10), jenis kelamin, umur pasien, bulan masuk pasien ke rumah sakit. Hasil penelitian menunjukkan bahwa ada 5 jenis klasifikasi penyakit, yaitu A00-B99, I00-I99, J00-J99, O00-O99 dan Z00Z99.

Penelitian mengenai klasifikasi data mining juga dilakukan oleh Yulia pada tahun 2016 [7] dalam bidang medis mengenai metode klasifikasi penyaki kanker servik, dalam penelitian ini, data yang digunakan diperoleh dari rekam medis hasil uji pap smear. Ada 38 gejala dan 7 kelas, Nä̈ve Bayes, Support Vector Machines (SVM), dan Random Forest Tree digunakan untuk mengevaluasi kinerja pengklasifikasi. Matrik kinerja yang digunakan dalam penelitian ini adalah akurasi, daya ingat, presisi, dan kurva ROC. Berdasarkan kinerja matrik, Random Forest Tree adalah classifier terbaik di antara pengklasifikasi lainnya untuk mengklasifikasikan hasil Pap smear
Penelitian lain juga dilakukan oleh Sucipto tahun 2016 [8], mengenai klasifikasi penyakit pada ikan, untuk memperoleh kualitas data dengan baik sehingga bisa untuk mengidentifikasi penyakit ikan. Kualitas hubungan data antara gejala penyakit ikan harus dipahami untuk diketahui akurasi klasifikasi yang diperoleh. Metode ini diperlukan untuk mengekstrak informasi dari data yang diperoleh. Ada banyak algoritma klasifikasi data mining tapi, algoritma C4.5 sesuai untuk penelitian ini digunakan untuk membentuk pohon keputusan.

\section{Metodologi Penelitian}

Penelitian fokus pada proses menganalisis data rekam medis dengan algoritma C4.5 menggunakan program RapidMiner Studio 7.5 (Tools Data Mining) untuk memperoleh hasil klasifikasi. Ada 4 atribut yang dipakai dalam penelitian, yaitu: (1) umur yang dikelompokkan dalam kategori bayi \& anak (umur $<15$ tahun), muda \& dewasa (umur 15- 50 tahun), tua (umur >50 tahun); (2) jenis kelamin yang terdiri dari perempuan (P) dan laki-laki (L); (3) bulan yang terdiri dari Januari, Februari, Maret, April, Mei, Juni, Juli, Agustus, September, Oktober, Nopember, Desember; (4) diagnosa (ICD-10) merupakan atribut tujuan yang terdiri dari kelompok penyakit sesuai kode penyakit internasional (ICD-10), yaitu: A00-B99, C00-D48, D50-D89, E00-E90, F00-F99, G00-G99, H00-H59, H60-H95, I00-I99, J00-J99, K00-K93, L00-L99, M00M99, N00-N99, O00-O99, P00-P96, Q00-Q99, R00R99, S00-T98, V01-Y98, Z00-Z99 [9].

Algoritma C4.5 dimulai dari proses memilih atribut dengan gain tertinggi sebagai akar pohon, kemudian membuat cabang untuk tiap-tiap nilai, lalu membagi kasus dalam cabang, setelah itu mengulangi proses untuk setiap cabang sampai semua kasus pada cabang memiliki kelas yang sama.

Untuk memudahkan dalam penerapan metodologi dan perancangan sistem maka dibuat bagan alir analisa dan perancangan seperti pada gambar 2 dibawah ini.

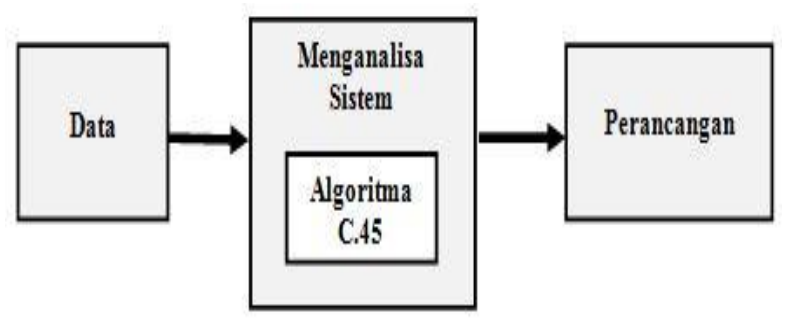

Gambar 2. Bagan Alir Analisa

Bentuk diagram alir (flowchart) dapat menggambarkan dengan jelas mengenai proses tahapan maupun langkah dalam klasifikasi menggunakan algoritma C4.5. Dapat dilihat dalam bentuk gambar 4.2 berupa flowchart sebagai berikut: 


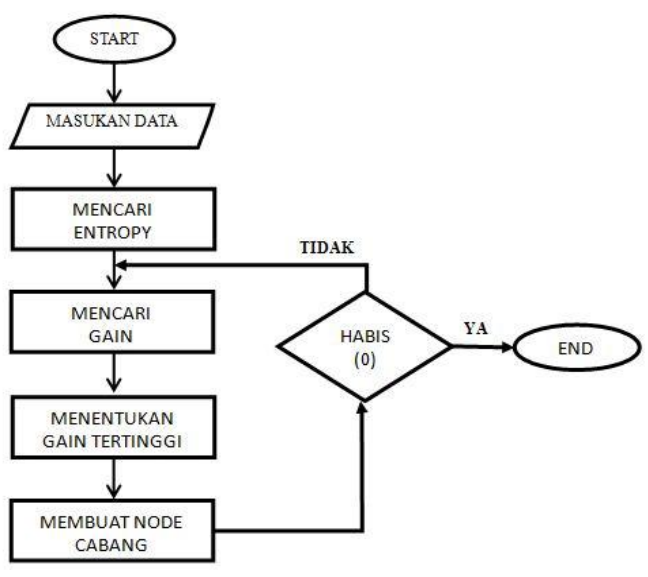

Gambar 3. Flowchart Proses pada Algoritma C4.5

pembentukan pohon keputusan, perlu menghitung dulu nilai informasi dalam satuan bits dari kumpulan objek.

Bentuk perhitungan untuk entropi adalah sebagai berikut :

$\operatorname{Entropy}(X)=\sum_{j=1}^{k} p_{j} * \log _{2} \frac{1}{p_{j}}=-\sum_{j=1}^{k} p_{j} * \log _{2} p_{j}$

dimana,

$$
\begin{aligned}
& X: \text { Himpunan Kasus } \\
& k: \text { jumlah partisi } \mathrm{X} \\
& p_{j}: \text { Proporsi } \mathrm{X}_{\mathrm{j}} \text { terhadap } \mathrm{X}
\end{aligned}
$$

Besar nilai Entropy $(X)$ menunjukkan bahwa X adalah atribut yang acak. Nilai entropi mencapai nilai minimum 0 , ketika semua $p_{j}$ lain $=0$ atau berada pada kelas yang sama. Pada kontruksi pohon $\mathrm{C} 4.5$, di setiap simpul pohon diisi oleh atribut dengan nilai gain ratio

Teknik Klasifikasi Algoritma C4.5 dimulai dengan tertinggi, dengan rumus sebagai berikut: processing dan transfromasi data agar data mentah yang digunakan untuk analisa adalah data dengan atribut yang lengkap dan dapat menghasilkan pohon keputusan, berikut urutan kerja untuk menentukan pohon keputusan

\subsection{Processing dan Transformasi Data}

Tidak semua atribut dalam database rekam medis pasien digunakan dalam penelitian, atribut seperti: tanggal lahir, nama dokter penanggung jawab dan nomor rekam medis pasien tidak dibutuhkan dalam penelitian ini.

Pengolahan hanya memerlukan empat buah atribut, seperti: Jenis Kelamin, Kategori Umur, Bulan Berobat dan Kode Penyakit sebagai atribut tujuan dari penelitian ini, sehingga diperlukan proses transformasi data yang akan diolah, setelah dilakukan transformasi data maka nantinya akan dilakukan pengolahan menggunakan algoritma C4.5, Sampel data yang telah dilakukan transformasi dapat dilihat pada tabel 1 dibawah ini

Tabel 1. Data Transformasi Rekam Medis Januari - Juni 2017

\begin{tabular}{cllll}
\hline No & Jenis Kelamin & $\begin{array}{c}\text { Kategori } \\
\text { Umur }\end{array}$ & Bulan & $\begin{array}{c}\text { Group } \\
\text { ICD }\end{array}$ \\
\hline 1 & Laki-Laki & Tua & Jan & J00-J99 \\
2 & Perempuan & Muda & Feb & E00-E90 \\
3 & Laki-Laki & Bayi \& Anak & Mar & H00-H59 \\
4 & Laki-Laki & Bayi \& Anak & Apr & A00-B99 \\
5 & Perempuan & Muda & Mei & I00-I99 \\
6 & Perempuan & Muda & Mei & I00-I99 \\
7 & Laki-Laki & Tua & Mei & I00-I99 \\
8 & Laki-Laki & Tua & Mei & I00-I99 \\
9 & Perempuan & Muda & Jun & I00-I99 \\
10 & Perempuan & Muda & Jun & I00-I99 \\
\hline
\end{tabular}

\subsubsection{Mencari Entropy Total dan Gain (Root)}

Proses pencarian entropi total dan gain dilakukan dengan mengelompokan data dengan benar, kemudian menghitung data serta menggunakan rumus pencarian

\begin{tabular}{|c|c|c|c|c|c|c|}
\hline \multicolumn{7}{|c|}{ Perhitungan Node 1} \\
\hline \multicolumn{2}{|c|}{ Jumlah Kasus } & $\begin{array}{c}\text { A00- } \\
\text { B99 }\end{array}$ & .. & $\begin{array}{l}\text { Z00- } \\
\text { Z99 }\end{array}$ & Ent. & Gain \\
\hline Total & 1000 & 21 & .. & 152 & 3,455 & \\
\hline \multicolumn{6}{|c|}{ Jenis Kelamin } & 1,346 \\
\hline $\mathrm{L}$ & 325 & 11 & .. & 101 & 0 & \\
\hline$\underline{P}$ & 675 & 10 & .. & 51 & 3,124 & \\
\hline \multicolumn{6}{|l|}{ Umur } & 0,555 \\
\hline$\overline{\mathrm{BA}}$ & 81 & 6 & .. & 17 & 0 & \\
\hline MD & 400 & 10 & .. & 58 & 3,324 & \\
\hline TUA & 519 & 5 & .. & 77 & 3,025 & \\
\hline \multicolumn{6}{|c|}{ Bulan } & 0,406 \\
\hline JAN & 141 & 1 & .. & 42 & 3,096 & \\
\hline FEB & 148 & 10 & .. & 44 & 2,883 & \\
\hline MAR & 105 & 3 & .. & 1 & 2,883 & \\
\hline APR & 353 & 1 & .. & 63 & 3,128 & \\
\hline MEI & 173 & 5 & .. & 1 & 3,141 & \\
\hline JUN & 80 & 1 & .. & 1 & 2,931 & \\
\hline
\end{tabular}
entropy dan gain pada masing-masing atribut data.

Tabel 2. Tabel Perhitungan Gain Tertinggi (Root)

Dari hasil perhitungan pada tabel diatas, dapat diketahui bahwa nilai gain terbesar yaitu pada atribut "Jenis Kelamin" sebesar 1,346. Sehingga atribut "Jenis Kelamin" menjadi node akar. Pada atribut "Jenis Kelamin" terdapat 2 nilai atribut, yaitu Laki-laki dan Perempuan, maka perlu dilakukan perhitungan lanjut. Dari proses tersebut maka dapat dihasilkan pohon sementara seperti berikut ini:

\subsection{Pengolahan Data}

Pengolahan data dimulai dengan mencari entropi total dari seluruh atribut dan kemudian menetukan gain tertinggi. Untuk mendapatkan nilai gain dalam 


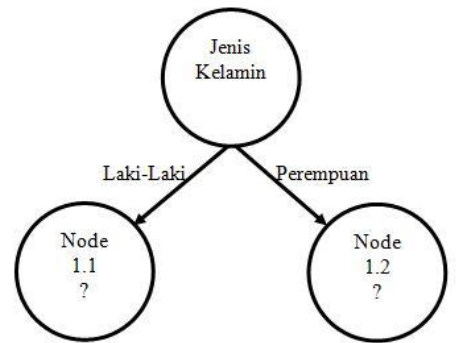

Gambar 4. Pohon Keputusan Sementara (Root)

\subsubsection{Mencari Node 1.1}

Perhitungan dilakukan untuk mencari node cabang atribut "Jenis Kelamin Laki-Laki" kemudian lakukan perhitungan mencari nilai gain terbesar untuk menjadi node cabang.

Tabel 3. Tabel Perhitungan Gain Tertinggi (Node 1.1)

\begin{tabular}{|c|c|c|c|c|c|c|}
\hline \multicolumn{7}{|c|}{ Node 1.1 (Jenis Kelamin_Laki-Laki) } \\
\hline $\begin{array}{l}\text { Banyak } \\
\text { Kasus }\end{array}$ & & $\begin{array}{l}\text { A00- } \\
\text { B99 }\end{array}$ &.$\cdot$ & $\begin{array}{l}\text { Z00- } \\
\text { Z99 }\end{array}$ & Ent. & Gain \\
\hline 325 & & 11 &.. & 101 & 3,525 & \\
\hline Umur & & & & & & 3,525 \\
\hline$\overline{\mathrm{BA}}$ & 42 & 1 & .. & 9 & 0 & \\
\hline MD & 72 & 7 & .. & 17 & 0 & \\
\hline TUA & 211 & 3 & .. & 75 & 0 & \\
\hline Bulan & & & & & & 3,525 \\
\hline JAN & 60 & 0 & .. & 42 & 0 & \\
\hline FEB & 62 & 2 & .. & 44 & 0 & \\
\hline MAR & 28 & 3 & .. & 0 & 0 & \\
\hline APR & 102 & 1 &.. & 15 & 0 & \\
\hline MEI & 68 & 5 & .. & 0 & 0 & \\
\hline JUN & 5 & 0 & .. & 0 & 0 & \\
\hline
\end{tabular}

Dari hasil perhitungan pada tabel diatas, dapat diketahui bahwa nilai gain terbesar yaitu sama besar pada atribut "Umur"dan atribut "Bulan" yaitu sebesar 3,525. Sehingga dapat dipilih diantara kedua atribut tersebut untuk dijadikan node cabang, dalam penelitian ini peneliti memilih atribut "Bulan" untuk dijadikan node cabang. Pada atribut "Bulan" terdapat 6 nilai atribut, yaitu Januari, Februari, Maret, April, Mei dan Juni, maka perlu dilakukan perhitungan lebih lanjut. Dari proses tersebut maka dapat dihasilkan pohon sementara seperti berikut ini:

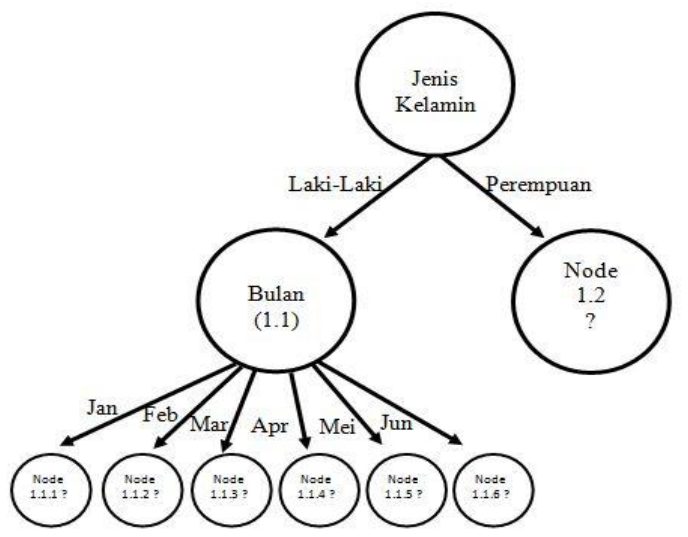

Gambar 5. Pohon Keputusan Sementara (Node 1.1)

\subsubsection{Mencari Node 1.1.1 - Node 1.1.6}

Perhitungan dilakukan untuk mencari node cabang atribut "Jenis Kelamin Laki-Laki" pada bulan Januari sampai Juni, kemudian lakukan perhitungan mencari nilai gain terbesar untuk menjadi node cabang.

Tabel 4. Tabel Perhitungan Gain Tertinggi (Node 1.1.1)

\begin{tabular}{lcccccc}
\hline \multicolumn{6}{l}{ Node 1.1.1 (Jenis Kelamin_Laki-Laki) (Bulan_Januari) } \\
\hline \multirow{2}{*}{ Banyak Kasus } & C00- & .. & Z00- & Ent. & Gain \\
& D48 & Z99 & En & \\
\hline \multicolumn{2}{c}{60} & 5 &.. & 42 & 1,567 & \\
\hline Umur & & & & & & 1,567 \\
\hline BA & 3 & 0 &.. & 0 & 0,0000 & \\
MD & 18 & 5 &.. & 13 & 0,0000 & \\
TUA & 39 & 0 &.. & 29 & 0,0000 & \\
\hline
\end{tabular}

Tabel 5. Tabel Perhitungan Gain Tertinggi (Node 1.1.2)

\begin{tabular}{|c|c|c|c|c|c|c|}
\hline \multicolumn{7}{|c|}{ Node 1.1.2 (Jenis Kelamin_Laki-Laki) (Bulan_Februari) } \\
\hline Banyal & asus & $\begin{array}{l}\text { A00- } \\
\text { B99 }\end{array}$ & .. & $\begin{array}{l}\text { Z00- } \\
\text { Z99 }\end{array}$ & Ent. & Gain \\
\hline \multicolumn{2}{|c|}{62} & 2 & .. & 44 & 1,644 & \\
\hline Umur & & & & & & 1,644 \\
\hline BA & 8 & 0 &. & 0 & 0,0000 & \\
\hline MD & 4 & 0 &. & 0 & 0,0000 & \\
\hline TUA & 50 & 2 &. & 44 & 0,0000 & \\
\hline
\end{tabular}

Tabel 6. Tabel Perhitungan Gain Tertinggi (Node 1.1.3)

\begin{tabular}{lcccccc}
\hline \multicolumn{6}{l}{ Node 1.1 .3 (Jenis Kelamin_Laki-Laki) (Bulan_Maret) } \\
\hline \multirow{2}{*}{ Banyak Kasus } & $\begin{array}{c}\text { A00- } \\
\text { B99 }\end{array}$ & .. & $\begin{array}{c}\text { Z00- } \\
\text { Z99 }\end{array}$ & Ent. & Gain \\
\hline \multicolumn{2}{c}{28} & 3 &.. & 1 & 2,263 & \\
\hline Umur & & & & & & 2,263 \\
\hline BA & 2 & 0 &.. & 0 & 0,0000 & \\
MD & 6 & 3 &.. & 0 & 0,0000 & \\
TUA & 20 & 0 &.. & 1 & 0,0000 & \\
\hline
\end{tabular}

Tabel 7. Tabel Perhitungan Gain Tertinggi (Node 1.1.4) Node 1.1.4 (Jenis Kelamin_Laki-Laki) (Bulan_April)

\begin{tabular}{lcccccc}
\hline \multirow{2}{*}{ Banyak Kasus } & $\begin{array}{c}\text { A00- } \\
\text { B99 }\end{array}$ &.. & $\begin{array}{c}\text { Z00- } \\
\text { Z99 }\end{array}$ & Ent. & Gain \\
\hline \multicolumn{2}{c}{102} & 1 &.. & 15 & 3,2306 & \\
\hline Umur & & & & & & 3,2306 \\
\hline BA & 25 & 1 &.. & 9 & 0,0000 & \\
MD & 32 & 0 &.. & 4 & 0,0000 & \\
TUA & 45 & 0 &.. & 2 & 0,0000 & \\
\hline
\end{tabular}

Tabel 8. Tabel Perhitungan Gain Tertinggi (Node 1.1.5)

\begin{tabular}{lcccccc}
\hline \multicolumn{6}{l}{ Node 1.1.5 (Jenis Kelamin_Laki-Laki) (Bulan_Mei) } \\
\hline \multirow{2}{*}{ Banyak Kasus } & $\begin{array}{c}\text { A00- } \\
\text { B99 }\end{array}$ & .. & $\begin{array}{c}\text { Z00- } \\
\text { Z99 }\end{array}$ & Ent. & Gain \\
\hline \multicolumn{2}{c}{68} & 5 &.. & 5 & 3,1469 & \\
\hline Umur & & & & & & 3,1469 \\
\hline BA & 3 & 0 &.. & 0 & 0,0000 & \\
MD & 11 & 4 &.. & 0 & 0,0000 & \\
TUA & 54 & 1 &.. & 5 & 0,0000 & \\
\hline
\end{tabular}

Tabel 9. Tabel Perhitungan Gain Tertinggi (Node 1.1.6)

\begin{tabular}{|c|c|c|c|c|c|c|}
\hline \multicolumn{7}{|c|}{ Node 1.1.6 (Jenis Kelamin_Laki-Laki) (Bulan_Juni) } \\
\hline \multicolumn{2}{|c|}{ Banyak Kasus } & $\begin{array}{c}\text { A00- } \\
\text { B99 }\end{array}$ & $\cdot \cdot$ & $\begin{array}{l}\text { Z00- } \\
\text { Z99 }\end{array}$ & Ent. & Gain \\
\hline \multicolumn{2}{|c|}{5} & 2 &.. & 2 & 1,5219 & \\
\hline Umur & & & & & & 0,3219 \\
\hline $\mathrm{BA}$ & 1 & 0 & .. & 1 & 0,0000 & \\
\hline MD & 0 & 0 & .. & 0 & 0,0000 & \\
\hline TUA & 4 & 2 & .. & 1 & 1,5000 & \\
\hline
\end{tabular}


Dari perhitungan tabel diatas, maka dapat dihasilkan pohon sementara seperti berikut ini:

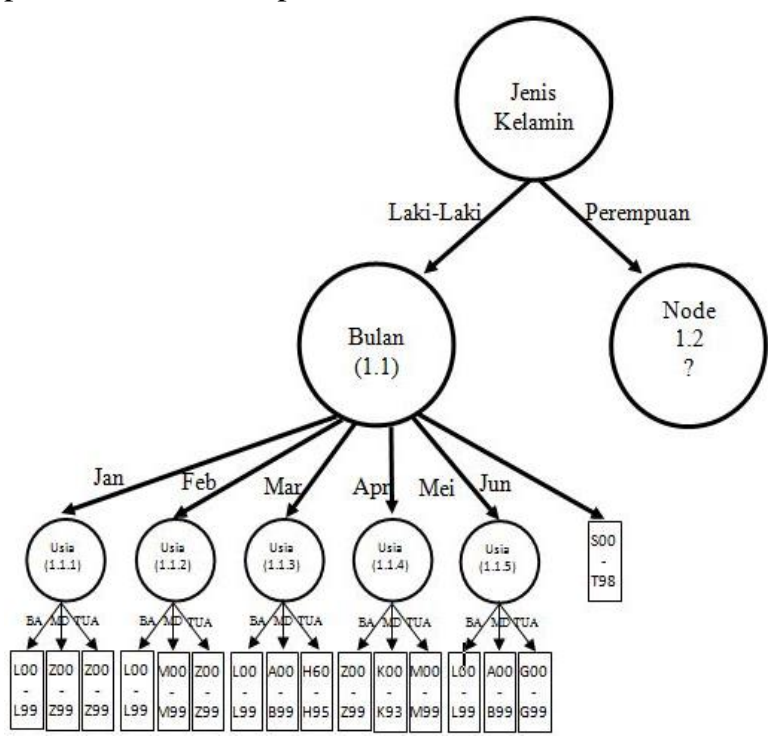

Gambar 6. Pohon Keputusan Sementara (Node 1.1.2 - Node 1.1.6)

\subsubsection{Mencari Node 1.2}

Perhitungan dilakukan untuk mencari node cabang atribut "Jenis Kelamin Perempuan", perhitungan dilakukan dengan mencari nilai dari atribut selain yang menjadi node akar (Jenis Kelamin), dan kemudian lakukan perhitungan untuk mencari nilai Gain dan atribut dengan nilai Gain terbesar, maka akan menjadi node cabang.

Tabel 10. Tabel Perhitungan Gain Tertinggi (Node 1.2)

\begin{tabular}{|c|c|c|c|c|c|c|}
\hline \multicolumn{7}{|c|}{ Node 1.1 (Jenis Kelamin_Perempuan) } \\
\hline $\begin{array}{l}\text { Banyal } \\
\text { Kasus }\end{array}$ & & $\begin{array}{c}\text { A00- } \\
\text { B99 }\end{array}$ &.. & $\begin{array}{l}\text { Z00- } \\
\text { Z99 }\end{array}$ & Ent. & Gain \\
\hline \multicolumn{2}{|c|}{325} & 10 & .. & 51 & 3,395 & \\
\hline \multicolumn{2}{|c|}{ Umur } & & & & & 3,349 \\
\hline$\overline{\mathrm{BA}}$ & 39 & 5 & .. & 8 & 0 & \\
\hline MD & 328 & 3 & .. & 41 & 0 & \\
\hline TUA & 308 & 2 & .. & 2 & 0 & \\
\hline \multicolumn{2}{|c|}{ Bulan } & & & & & 3,021 \\
\hline$\overline{\mathrm{JAN}}$ & 81 & 1 & .. & 0 & 0 & \\
\hline FEB & 86 & 8 & .. & 0 & 0 & \\
\hline MAR & 77 & 1 & .. & 1 & 0 & \\
\hline APR & 251 & 0 & .. & 48 & 0 & \\
\hline MEI & 105 & 0 & .. & 1 & 0 & \\
\hline JUN & 75 & 1 & .. & 1 & 0 & \\
\hline
\end{tabular}

Dari hasil perhitungan pada tabel diatas, dapat diketahui bahwa nilai gain terbesar pada atribut "Umur" yaitu sebesar 3,349. Pada atribut "Umur" terdapat 3 nilai atribut, yaitu Bayi dan Anak, Muda dan Dewasa serta Tua, maka perlu dilakukan perhitungan lebih lanjut.

Dari proses tersebut maka dapat dihasilkan pohon sementara seperti berikut ini:

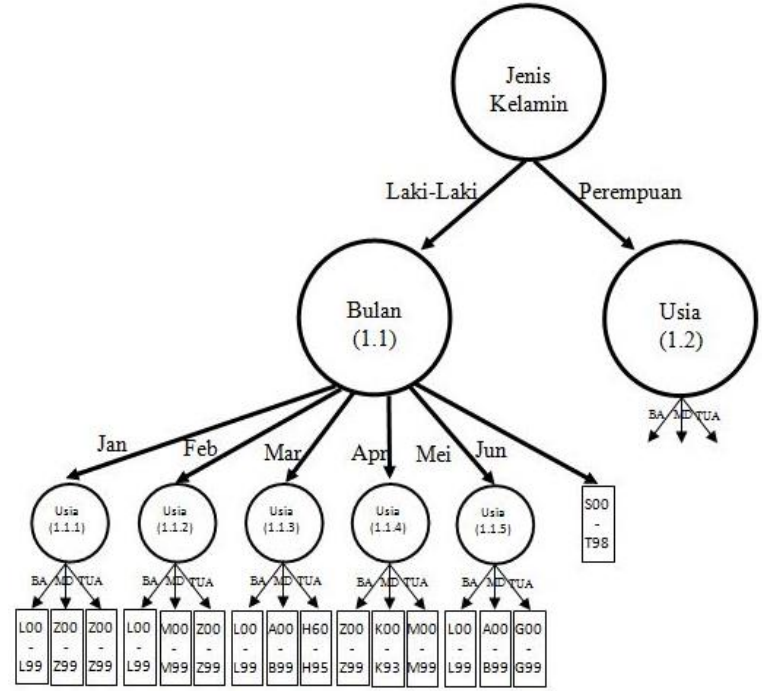

Gambar 7. Pohon Keputusan Sementara (Node 1.2)

\subsubsection{Mencari Node 1.2.1 - Node 1.2.3}

Perhitungan dilakukan untuk mencari node cabang atribut "Jenis Kelamin Prempuan" pada kategori umur Balita, Muda dan Tua, lakukan perhitungan nilai gain terbesar untuk node cabang

Tabel 11. Tabel Perhitungan Gain Tertinggi (Node 1.2.1)

\begin{tabular}{lcccccc}
\hline \multicolumn{6}{l}{ Node 1.2.1 (Jenis Kelamin_Perempuan (Usia_Bayi\&Anak) } \\
\hline $\begin{array}{l}\text { Banyak } \\
\text { Kasus }\end{array}$ & A00- & $\ldots \ldots \ldots$ & Z00- & Ent. & Gain \\
\hline \multicolumn{1}{c}{ B99 } & 5 & $\ldots \ldots \ldots .$. & Z99 & & \\
\hline Bulan & & $\ldots \ldots \ldots$ & 8 & 3,2818 & \\
\hline JAN & 4 & 0 & $\ldots \ldots \ldots$. & 0 & 0,0000 & 3,2818 \\
FEB & 7 & 5 & $\ldots \ldots \ldots$. & 0 & 0,0000 & \\
MAR & 4 & 0 & $\ldots \ldots \ldots$. & 0 & 0,0000 & \\
APR & 12 & 0 & $\ldots \ldots \ldots$. & 8 & 0,0000 & \\
MEI & 11 & 0 & $\ldots \ldots \ldots$. & 0 & 0,0000 & \\
JUN & 1 & 0 & $\ldots \ldots \ldots$. & 0 & 0,0000 & \\
\hline
\end{tabular}

Tabel 12. Tabel Perhitungan Gain Tertinggi (Node 1.2.2)

\begin{tabular}{lcccccc}
\hline \multicolumn{6}{l}{ Node 1.2.2 (Jenis Kelamin_Perempuan (Usia_Muda\&Dewasa) } \\
\hline Banyak & A00- & $\ldots$ & Z00- & Ent. & Gain \\
Kasus & B99 & $\ldots \ldots \ldots$. & Z99 & & \\
\hline \multicolumn{1}{c}{39} & 3 & $\ldots \ldots \ldots$. & 41 & 3,094 & \\
\hline Bulan & & & & & 3,094 \\
\hline JAN & 42 & 0 & $\ldots \ldots \ldots$. & 0 & 0,0000 & \\
FEB & 40 & 3 & $\ldots \ldots \ldots$. & 0 & 0,0000 & \\
MAR & 30 & 0 & $\ldots \ldots \ldots$. & 0 & 0,0000 & \\
APR & 159 & 0 & $\ldots \ldots \ldots$. & 40 & 0,0000 & \\
MEI & 30 & 0 & $\ldots \ldots \ldots$. & 1 & 0,0000 & \\
JUN & 27 & 0 & $\ldots \ldots \ldots$. & 0 & 0,0000 & \\
\hline
\end{tabular}

Tabel 13. Tabel Perhitungan Gain Tertinggi (Node 1.2.3)

\begin{tabular}{|c|c|c|c|c|c|}
\hline \multicolumn{6}{|c|}{ Node 1.2.3 (Jenis Kelamin_Perempuan (Usia_Tua) } \\
\hline $\begin{array}{l}\text { Banyak } \\
\text { Kasus }\end{array}$ & $\begin{array}{l}\text { A00- } \\
\text { B99 }\end{array}$ & ............. & $\begin{array}{l}\text { Z00- } \\
\text { Z99 }\end{array}$ & Ent. & Gain \\
\hline 308 & 2 & ........... & 2 & 2,777 & \\
\hline Bulan & & & & & 2,777 \\
\hline JAN 35 & 1 & $\ldots$ & 0 & 0,0000 & \\
\hline FEB & 0 & ............ & 0 & 0,0000 & \\
\hline MAR 43 & 0 & .................. & 1 & 0,0000 & \\
\hline APR 80 & 0 & .............. & 0 & 0,0000 & \\
\hline MEI & 0 & ............ & 0 & 0,0000 & \\
\hline JUN 47 & 1 & ............ & 1 & 0,0000 & \\
\hline
\end{tabular}


Dari perhitungan tabel diatas, maka dapat dihasilkan pohon keputusan yang telah digabungkan dengan pohon keputusan sebelumnya, seperti berikut ini:

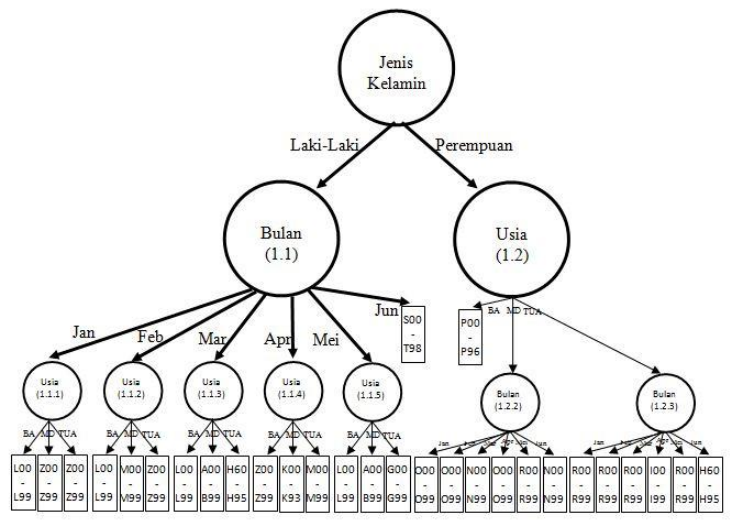

Gambar 8. Pohon Keputusan Akhir

Untuk lebih jelasnya, hasil dalam pohon keputusan dapat menghasilkan rule seperti dapat dilihat pada tabel 14 seperti dibawah ini:

Tabel 14. Rule Knowledge

\begin{tabular}{|c|c|c|}
\hline \multirow[t]{2}{*}{$\begin{array}{c}\text { Rule } \\
1\end{array}$} & IF & $\begin{array}{l}\text { Jenis Kelamin =Laki-Laki and } \\
\text { Bulan = Januari and } \\
\text { Usia = Balita dan Anak }\end{array}$ \\
\hline & THEN & Kode Penyakit = L00 - L99 \\
\hline \multirow[t]{2}{*}{$\begin{array}{c}\text { Rule } \\
2\end{array}$} & IF & $\begin{array}{l}\text { Jenis Kelamin =Laki-Laki and } \\
\text { Bulan = Januari and } \\
\text { Usia = Muda dan Dewasa }\end{array}$ \\
\hline & THEN & Kode Penyakit $=$ Z00 - Z99 \\
\hline \multirow[t]{2}{*}{$\begin{array}{c}\text { Rule } \\
3\end{array}$} & IF & $\begin{array}{l}\text { Jenis Kelamin =Laki-Laki and } \\
\text { Bulan = Januari and } \\
\text { Usia = Tua }\end{array}$ \\
\hline & THEN & Kode Penyakit = Z00 - Z99 \\
\hline \multirow[t]{2}{*}{$\begin{array}{c}\text { Rule } \\
4\end{array}$} & IF & $\begin{array}{l}\text { Jenis Kelamin =Laki-Laki and } \\
\text { Bulan = Februari and } \\
\text { Usia = Balita dan Anak }\end{array}$ \\
\hline & THEN & Kode Penyakit = L00 - L99 \\
\hline \multirow[t]{2}{*}{$\begin{array}{c}\text { Rule } \\
5\end{array}$} & IF & $\begin{array}{l}\text { Jenis Kelamin =Laki-Laki and } \\
\text { Bulan = Februari and } \\
\text { Usia = Muda dan Dewasa }\end{array}$ \\
\hline & THEN & Kode Penyakit = M00 - M99 \\
\hline \multirow[t]{2}{*}{$\begin{array}{c}\text { Rule } \\
6\end{array}$} & IF & $\begin{array}{l}\text { Jenis Kelamin =Laki-Laki and } \\
\text { Bulan = Februari and } \\
\text { Usia = Tua }\end{array}$ \\
\hline & THEN & Kode Penyakit = Z00 - Z99 \\
\hline \multirow[t]{2}{*}{$\begin{array}{c}\text { Rule } \\
7\end{array}$} & IF & $\begin{array}{l}\text { Jenis Kelamin =Laki-Laki and } \\
\text { Bulan = Maret and } \\
\text { Usia = Balita dan Anak }\end{array}$ \\
\hline & THEN & Kode Penyakit = L00 - L99 \\
\hline \multirow[t]{2}{*}{$\begin{array}{c}\text { Rule } \\
8\end{array}$} & IF & $\begin{array}{l}\text { Jenis Kelamin =Laki-Laki and } \\
\text { Bulan = Maret and } \\
\text { Usia = Muda dan Dewasa }\end{array}$ \\
\hline & THEN & Kode Penyakit $=$ A00 - B99 \\
\hline \multirow[t]{2}{*}{$\begin{array}{c}\text { Rule } \\
9\end{array}$} & IF & $\begin{array}{l}\text { Jenis Kelamin =Laki-Laki and } \\
\text { Bulan = Maret and } \\
\text { Usia = Tua }\end{array}$ \\
\hline & THEN & Kode Penyakit = H60 - H95 \\
\hline \multirow[t]{2}{*}{$\begin{array}{c}\text { Rule } \\
10\end{array}$} & IF & $\begin{array}{l}\text { Jenis Kelamin =Laki-Laki and } \\
\text { Bulan = April and } \\
\text { Usia = Balita dan Anak }\end{array}$ \\
\hline & THEN & Kode Penyakit $=$ Z00 - Z99 \\
\hline $\begin{array}{c}\text { Rule } \\
11\end{array}$ & IF & $\begin{array}{l}\text { Jenis Kelamin =Laki-Laki and } \\
\text { Bulan = April and } \\
\text { Usia = Muda dan Dewasa }\end{array}$ \\
\hline
\end{tabular}

\begin{tabular}{|c|c|c|}
\hline & THEN & Kode Penyakit $=$ K00 - K93 \\
\hline \multirow[t]{2}{*}{$\begin{array}{c}\text { Rule } \\
12\end{array}$} & IF & $\begin{array}{l}\text { Jenis Kelamin =Laki-Laki and } \\
\text { Bulan = April and } \\
\text { Usia = Tua }\end{array}$ \\
\hline & THEN & Kode Penyakit = M00 - M99 \\
\hline \multirow[t]{2}{*}{$\begin{array}{c}\text { Rule } \\
13\end{array}$} & IF & $\begin{array}{l}\text { Jenis Kelamin =Laki-Laki and } \\
\text { Bulan = Mei and } \\
\text { Usia = Balita dan Anak }\end{array}$ \\
\hline & THEN & Kode Penyakit = L00 - L99 \\
\hline \multirow[t]{2}{*}{$\begin{array}{c}\text { Rule } \\
14\end{array}$} & IF & $\begin{array}{l}\text { Jenis Kelamin =Laki-Laki and } \\
\text { Bulan = Mei and } \\
\text { Usia = Muda dan Dewasa }\end{array}$ \\
\hline & THEN & Kode Penyakit = A00 - B99 \\
\hline \multirow[t]{2}{*}{$\begin{array}{c}\text { Rule } \\
15\end{array}$} & IF & $\begin{array}{l}\text { Jenis Kelamin =Laki-Laki and } \\
\text { Bulan = Mei and } \\
\text { Usia = Tua }\end{array}$ \\
\hline & THEN & Kode Penyakit = G00 - G99 \\
\hline \multirow{2}{*}{$\begin{array}{l}\text { Rule } \\
16\end{array}$} & IF & $\begin{array}{l}\text { Jenis Kelamin =Laki-Laki and } \\
\text { Bulan = Juni }\end{array}$ \\
\hline & THEN & Kode Penyakit = S00 - T98 \\
\hline \multirow{2}{*}{$\begin{array}{c}\text { Rule } \\
17\end{array}$} & IF & $\begin{array}{l}\text { Jenis Kelamin = Perempuan and } \\
\text { Usia = Balita dan Anak }\end{array}$ \\
\hline & THEN & Kode Penyakit = P00 - P96 \\
\hline \multirow[t]{2}{*}{$\begin{array}{c}\text { Rule } \\
18\end{array}$} & IF & $\begin{array}{l}\text { Jenis Kelamin = Perempuan and } \\
\text { Usia = Muda dan Dewasa and } \\
\text { Bulan = Januari }\end{array}$ \\
\hline & THEN & Kode Penyakit = O00 - O99 \\
\hline \multirow[t]{2}{*}{$\begin{array}{c}\text { Rule } \\
19\end{array}$} & IF & $\begin{array}{l}\text { Jenis Kelamin = Perempuan and } \\
\text { Usia = Muda dan Dewasa and } \\
\text { Bulan = Februari }\end{array}$ \\
\hline & THEN & Kode Penyakit = O00 - O99 \\
\hline \multirow[t]{2}{*}{$\begin{array}{c}\text { Rule } \\
20\end{array}$} & IF & $\begin{array}{l}\text { Jenis Kelamin = Perempuan and } \\
\text { Usia = Muda dan Dewasa and } \\
\text { Bulan = Maret }\end{array}$ \\
\hline & THEN & Kode Penyakit = N00 - N99 \\
\hline \multirow[t]{2}{*}{$\begin{array}{c}\text { Rule } \\
21\end{array}$} & IF & $\begin{array}{l}\text { Jenis Kelamin = Perempuan and } \\
\text { Usia = Muda dan Dewasa and } \\
\text { Bulan = April }\end{array}$ \\
\hline & THEN & Kode Penyakit = O00 - O99 \\
\hline \multirow[t]{2}{*}{$\begin{array}{c}\text { Rule } \\
22\end{array}$} & IF & $\begin{array}{l}\text { Jenis Kelamin = Perempuan and } \\
\text { Usia = Muda dan Dewasa and } \\
\text { Bulan = Mei }\end{array}$ \\
\hline & THEN & Kode Penyakit = R00 - R99 \\
\hline \multirow[t]{2}{*}{$\begin{array}{c}\text { Rule } \\
23\end{array}$} & IF & $\begin{array}{l}\text { Jenis Kelamin = Perempuan and } \\
\text { Usia = Muda dan Dewasa and } \\
\text { Bulan = Juni }\end{array}$ \\
\hline & THEN & Kode Penyakit = N00 - N99 \\
\hline \multirow[t]{2}{*}{$\begin{array}{c}\text { Rule } \\
24\end{array}$} & IF & $\begin{array}{l}\text { Jenis Kelamin = Perempuan and } \\
\text { Usia = Tua and } \\
\text { Bulan = Januari }\end{array}$ \\
\hline & THEN & Kode Penyakit = R00 - R99 \\
\hline \multirow[t]{2}{*}{$\begin{array}{c}\text { Rule } \\
25\end{array}$} & IF & $\begin{array}{l}\text { Jenis Kelamin = Perempuan and } \\
\text { Usia = Tua and } \\
\text { Bulan = Februari }\end{array}$ \\
\hline & THEN & Kode Penyakit = R00 - R99 \\
\hline \multirow[t]{2}{*}{$\begin{array}{c}\text { Rule } \\
26\end{array}$} & IF & $\begin{array}{l}\text { Jenis Kelamin = Perempuan and } \\
\text { Usia = Tua and } \\
\text { Bulan = Maret }\end{array}$ \\
\hline & THEN & Kode Penyakit = R00 - R99 \\
\hline \multirow[t]{2}{*}{$\begin{array}{c}\text { Rule } \\
27\end{array}$} & IF & $\begin{array}{l}\text { Jenis Kelamin = Perempuan and } \\
\text { Usia = Tua and } \\
\text { Bulan = April }\end{array}$ \\
\hline & THEN & Kode Penyakit = I00 - I99 \\
\hline \multirow[t]{2}{*}{$\begin{array}{c}\text { Rule } \\
28\end{array}$} & IF & $\begin{array}{l}\text { Jenis Kelamin = Perempuan and } \\
\text { Usia = Tua and } \\
\text { Bulan = Mei }\end{array}$ \\
\hline & THEN & Kode Penyakit = R00 - R99 \\
\hline \multirow[t]{2}{*}{$\begin{array}{c}\text { Rule } \\
29\end{array}$} & IF & $\begin{array}{l}\text { Jenis Kelamin = Perempuan and } \\
\text { Usia = Tua and } \\
\text { Bulan = Juni }\end{array}$ \\
\hline & THEN & Kode Penyakit $=$ H60 $-\mathrm{H} 95$ \\
\hline
\end{tabular}




\section{Hasil dan Pembahasan}

Hasil analisa menunjukan bahwa algoritma C4.5 berhasil mengelompokan penyakit ke dalam 13 jenis kategori dari 21 jenis kategori yang menjadi label tujuan berdasarkan ICD (International Code Diseases) atau kode penyakit internasional, sehingga dapat dikatakan bahwa Algoritma C4.5 berhasil mendefinisikan $\mathbf{6 1 , 9 \%}$ dari kategori label tujuan yang ada.

Hasil pengujian terhadap data yang telah dilakukan, dirangkum pada tabel 15 seperti dibawah ini:

Tabel 15. Hasil Pengujian Data

\begin{tabular}{|c|c|c|c|}
\hline No & $\begin{array}{l}\text { Group } \\
\text { ICD }\end{array}$ & Klasifikasi & Keterangan \\
\hline 1 & A00-B99 & $\mathrm{ADA}$ & $\begin{array}{l}\text { Terklasifikasikan sebagai } \\
\text { leaf node (label) }\end{array}$ \\
\hline 4 & E00-E90 & TIDAK & $\begin{array}{l}\text { Kasus yang terjadi untuk } \\
\text { grup penyakit pada ICD } \\
\text { "E00-E90" sangat sedikit, } \\
\text { hanya terjadi } 14 \text { kali } \\
\text { selama bulan Januari } \\
\text { sampai dengan bulan Juni } \\
2017 \text {, dengan presentasi } \\
\text { data sebesar } 1,4 \%\end{array}$ \\
\hline 5 & F00-F99 & TIDAK & $\begin{array}{l}\text { Kasus yang terjadi untuk } \\
\text { grup penyakit pada ICD } \\
\text { "F00-F99" sangat sedikit, } \\
\text { hanya terjadi } 18 \text { kali } \\
\text { selama bulan Januari } \\
\text { sampai dengan bulan Juni } \\
\text { 2017, dengan presentasi } \\
\text { data sebesar } 1,8 \%\end{array}$ \\
\hline 6 & G00-G99 & $\mathrm{ADA}$ & $\begin{array}{l}\text { Terklasifikasikan sebagai } \\
\text { leaf node (label) }\end{array}$ \\
\hline 7 & H00-H59 & TIDAK & $\begin{array}{l}\text { Kasus yang terjadi untuk } \\
\text { grup penyakit pada ICD } \\
\text { "H00-H59" sangat sedikit, } \\
\text { hanya terjadi } 12 \text { kali } \\
\text { selama bulan Januari } \\
\text { sampai dengan bulan Juni } \\
2017 \text {, dengan presentasi } \\
\text { data sebesar } 1,2 \%\end{array}$ \\
\hline 8 & H60-H95 & $\mathrm{ADA}$ & $\begin{array}{l}\text { Terklasifikasikan sebagai } \\
\text { leaf node (label) }\end{array}$ \\
\hline 9 & I00-I99 & $\mathrm{ADA}$ & $\begin{array}{l}\text { Terklasifikasikan sebagai } \\
\text { leaf node (label) }\end{array}$ \\
\hline 10 & J00-J99 & TIDAK & $\begin{array}{l}\text { Kasus yang terjadi untuk } \\
\text { grup penyakit pada ICD } \\
\text { "J00-J99" sangat sedikit, } \\
\text { hanya terjadi } 17 \text { kali } \\
\text { selama bulan Januari } \\
\text { sampai dengan bulan Juni } \\
2017 \text {, dengan presentasi } \\
\text { data sebesar } 1,7 \%\end{array}$ \\
\hline 11 & K00-K93 & $\mathrm{ADA}$ & $\begin{array}{l}\text { Terklasifikasikan sebagai } \\
\text { leaf node (label) }\end{array}$ \\
\hline 12 & L00-L99 & $\mathrm{ADA}$ & $\begin{array}{l}\text { Terklasifikasikan sebagai } \\
\text { leaf node (label) }\end{array}$ \\
\hline 13 & M00-M99 & $\mathrm{ADA}$ & $\begin{array}{l}\text { Terklasifikasikan sebagai } \\
\text { leaf node (label) }\end{array}$ \\
\hline 14 & N00-N99 & $\mathrm{ADA}$ & $\begin{array}{l}\text { Terklasifikasikan sebagai } \\
\text { leaf node (label) }\end{array}$ \\
\hline 15 & O00-O99 & $\mathrm{ADA}$ & $\begin{array}{l}\text { Terklasifikasikan sebagai } \\
\text { leaf node (label) }\end{array}$ \\
\hline 16 & P00-P96 & $\mathrm{ADA}$ & $\begin{array}{l}\text { Terklasifikasikan sebagai } \\
\text { leaf node (label) }\end{array}$ \\
\hline
\end{tabular}

Kasus yang terjadi untuk grup penyakit pada ICD "F00-F99" sangat sedikit, 17 Q00-Q99 TIDAK hanya terjadi 8 kali selama bulan Januari sampai dengan bulan Juni 2017, dengan presentasi data sebesar $0,8 \%$

\begin{tabular}{|c|c|c|c|}
\hline 18 & R00-R99 & $\mathrm{ADA}$ & $\begin{array}{l}\text { Terklasifikasikan sebagai } \\
\text { leaf node (label) }\end{array}$ \\
\hline 19 & S00-T98 & ADA & $\begin{array}{l}\text { Terklasifikasikan sebagai } \\
\text { leaf node (label) }\end{array}$ \\
\hline 2 & C00-D48 & TIDAK & $\begin{array}{l}\text { Kasus yang terjadi untuk } \\
\text { grup penyakit pada ICD } \\
\text { "C00-D48" sangat sedikit, } \\
\text { hanya terjadi } 13 \text { kali } \\
\text { selama bulan Januari } \\
\text { sampai dengan bulan Juni } \\
2017 \text {, dengan presentasi } \\
\text { data sebesar } 1,3 \%\end{array}$ \\
\hline 3 & D50-D89 & TIDAK & $\begin{array}{l}\text { Kasus yang terjadi untuk } \\
\text { grup penyakit pada ICD } \\
\text { "D50-D89" sangat sedikit, } \\
\text { hanya terjadi } 9 \text { kali selama } \\
\text { bulan Januari sampai } \\
\text { dengan bulan Juni } 2017 \text {, } \\
\text { dengan presentasi data } \\
\text { sebesar } 0,9 \%\end{array}$ \\
\hline 20 & V01-Y98 & TIDAK & $\begin{array}{l}\text { Tidak ada kasus yang } \\
\text { terjadi untuk grup penyakit } \\
\text { pada ICD "V01-Y98", } \\
\text { dengan presentasi data } \\
\text { sebesar } 0 \%\end{array}$ \\
\hline 21 & Z00-Z99 & ADA & $\begin{array}{l}\text { Terklasifikasikan sebagai } \\
\text { leaf node (label) }\end{array}$ \\
\hline
\end{tabular}

\section{Kesimpulan}

Hasil pengujian algoritma C4.5 yang telah dilakukan, terdapat beberapa kesimpulan serta saran yang berhubungan dengan pembahasan sebelumnya.

\subsection{Simpulan}

1. Teknik klasifikasi menggunakan algoritma $\mathrm{C} 4.5$ membantu mengklasifikasikan data rekam medis pasien Rumah Sakit Tamar Medical Centre (TMC) Kota Pariaman sesuai dengan kode penyakit internasional.

2. Algoritma C4.5 dengan output pohon keputusan memberikan informasi rule diagnosa kode penyakit yang sering terjadi dengan mengklasifikasikan diagnosa penyakit berdasarkan jenis kelamin, umur dan tanggal pasien dirawat.

3. Algoritma C4.5 mengelompokan penyakit ke dalam 13 jenis kategori dari 21 jenis kategori yang menjadi label tujuan berdasarkan ICD (International Code Diseases) atau kode penyakit internasional, sehingga Algoritma C4.5 berhasil mendefinisikan label tujuan sebesar $61,90 \%$ 


\subsection{Saran}

Beberapa saran yang dapat diperhatikan untuk masa yang akan datang maupun untuk pengembangan lebih lanjut terhadap pengklasifikasian data rekam medis pasien adalah sebagai berikut:

1. Penelitian ini diharapkan dapat dikembangkan lagi dengan menambah lebih banyak data, sehingga tingkat akurasi atribut label tujuan semakin mewakili data yang ada.

2. Penambahan variabel atau atribut lainnya sangat $[8$ diperlukan atau dalam kata lain perlu penelitian lebih lanjut baik di lapangan maupun berdasarkan data yang ada guna menghasilkan rule yang tepat.

3. Belum adanya pembanding software yang dilakukan penulis, misalnya terhadap Software Data Mining lainnya seperti Weka, Orange, Tanagra, dan lainnya.Perbandingan ini juga perlu dilakukan guna melihat hasil dari pengolahan yang dilakukan terhadap software yang digunakan.

\section{Daftar Rujukan}

[1] Pupezescu, V., 2016. The Influence of Data Replication in the Knowledge Discovery in Distributed Databases Process. ECAI 2016 International Conference Electronics (Computers and Artificial Intelligence), 8th Edition, pp.17

[2] Priyadharsini, C., 2014. An Overview of Knowledge Discovery Database and Data mining Techniques. International Journal of Innovative Research in Computer and Communication Engineering, Vol.2 (Special Issue 1), pp.1571-1572

[3] Veenita K., 2016. Chronic Kidney Disease Analysis Using Data Mining Classification Techniques. IEEE, pp.300-305

[4] Harvinder C. and Anu C., 2013. Implementation of decision tree C4.5 algorithm. International Journal of Scientific and Research Publications, Vol. 3(10)
[5] Chauhan H. and Chauhan A., 2013. Implementation of decision tree C4.5 algorithm. International Journal of Scientific and Research Publications, Vol. 3(Issue 10)

[6] Wenefrida, T.I., 2013. Klasifikasi Data Rekam Medis Berdasarkan Kode Penyakit Internasional Menggunakan Algoritma C4.5. Jurnal Media Elektro, Vol.1(3), pp.105

[7] Yulia, E.K., Adhistya E.P., Silmi F., 2016. Comparative Study on Data Mining Classification Methods for Cervical Cancer Prediction Using Pap Smear Results. 1st International Conference on Biomedical Engineering (IBIOMED), pp.1

Sucipto, Kusrini, Emha L.T., 2016. Classification Method of Multi-class on C4.5 Algorithm for Fish Diseases. 2016 2nd International Conference on Science in Information Technology (ICSITech), pp.5

[9] WHO. 2010. International Statistical Classification of Diseases and Related Health Problems (ICD-10). 